\title{
Selling the peace? Corruption and post- conflict peacebuilding
}

Book or Report Section

Accepted Version

Chapter proofs

Cheng, C. and Zaum, D. (2011) Selling the peace? Corruption and post-conflict peacebuilding. In: Cheng, C. and Zaum, D. (eds.) Corruption and Post-conflict Peacebuilding: Selling the peace? Cass Series on Peacekeeping. Routledge, Abingdon, pp. 1-25. ISBN 9780415620482 Available at https://centaur.reading.ac.uk/23482/

It is advisable to refer to the publisher's version if you intend to cite from the work. See Guidance on citing.

Publisher: Routledge

All outputs in CentAUR are protected by Intellectual Property Rights law, including copyright law. Copyright and IPR is retained by the creators or other copyright holders. Terms and conditions for use of this material are defined in the End User Agreement.

\section{www.reading.ac.uk/centaur}

\section{CentAUR}

Central Archive at the University of Reading 
Reading's research outputs online 


\title{
1 Selling the peace? Corruption and post-conflict peacebuilding
}

\author{
Christine Cheng and Dominik Zaum ${ }^{1}$
}

Corruption has become an increasingly salient issue in war to peace transitions, both for the populations of war-torn countries and for the donor governments, NGOs, and international and regional organisations involved in peacebuilding efforts. Conflict-affected countries feature prominently in corruption surveys as having the most serious corruption problems (Transparency International 2010; World Bank 2010). They offer an ideal environment for pervasive corruption: with their weak administrative institutions and often broken legal and judicial systems, they lack the capacity to effectively investigate and enforce prohibitions of corrupt behaviour. Moreover, the social norms that are expected to contain corruption tend to be weak or non-existent; and divisions within societies affected by conflict weaken shared conceptions of the public good (Sandholtz and Koetzle 2000: 36; Philp in this volume). Further, the sudden inflow of donor aid and the desire of external actors to disburse it quickly create ample incentives and opportunities for corruption (Wilder and Gordon 2009).

That countries with weak institutions and weak shared conceptions of the public good are more prone to corruption is not a new insight (see for example Nye 1967: 418). The fact that it has become a major preoccupation for peacebuilding actors and analysts in recent years is a consequence of the broad scope of peacebuilding (Barnett et al. 2007), defined in Boutros Boutros-Ghali's Agenda for Peace as 'actions to identify and support structures which will tend to strengthen and solidify peace in order to avoid a relapse into conflict' (UN 1992). In particular, peacebuilding's focus on socio-economic development and the reform and strengthening of political and administrative structures are strongly affected by corruption. This focus reflects two intellectual developments in particular. The first is the recognition of the importance of war economies in perpetuating conflict, and of the persistence of power structures rooted in war economies well into peacetime, where they become entrenched and consolidated through corruption (Berdal and Malone 2000; Berdal and Zaum 2011; Cheng 2011; Cramer 2006; Pugh et al. 2004). In addition to contributing to the outbreak of war and sustaining it, the political 


\section{C. Cheng and D. Zaum}

economy of conflict also shapes the possibilities and the character of the peace that follows, as well as the efforts of local and external actors to shape that peace.

The second is the increased focus by many donor governments and international organisations on statebuilding as an essential part of peacebuilding, even though the latter encompasses a wide range of practices. As the weakness or even collapse of state institutions came to be seen as sources of conflict, peacebuilding and statebuilding have also been used interchangeably at times. Functioning institutions that can help to manage conflicts over power, resources and identity in divided societies, and that can effectively deliver key public goods such as security and justice are undoubtedly central to post-conflict stability (Call and Wyeth 2008; Paris 2004; Zaum 2007).This emphasis on the role of political institutions and political economy in post-conflict peacebuilding has increasingly shifted the attention of peacebuilders towards the issue of corruption.

Closely associated with market distortion and the malfunction of political institutions, corruption is considered a key challenge to consolidating peace, hindering economic development, perpetuating the unjust distribution of public resources and undermining the legitimacy and effectiveness of government (Mauro 1997b; Rose-Ackerman 1999; Seligson 2002; Senior 2006). In recent years, there has been a growing literature on the impact of corruption after conflict (Boucher et al. 2007; Large 2005; Le Billon 2003, 2005; O'Donnell 2008). This book aims to contribute to this debate by examining the specific conceptual and political challenges that corruption poses to post-conflict peacebuilding.

In referring to 'post-conflict' countries, it is important to clarify that we are referring to states that have reached a formal peace agreement, even though violence, including armed conflict might still be pervasive. While peace agreements do not necessarily end violence, and the distinction between conflict and post-conflict might not be as meaningful to individuals on the ground who continue to experience violence in the 'postconflict' period, peace agreements set a framework under which peace can take hold (Höglund 2008). Thus, despite the obvious shortcomings of the term, post-conflict remains a useful descriptor for our purposes.

Across the different chapters in this volume, a complex set of issues emerges to shape our understanding of post-conflict corruption, its impact on stability and development, and the consequences of anti-corruption initiatives in the context of peacebuilding efforts. The chapters explore several questions:

- What specific forms does corruption take in conflict and post-conflict environments?

- How do different forms of corruption affect the outcomes of peacebuilding efforts? 
- How, and to what extent, do particular peacebuilding practices fuel corruption?

- What have been the main efforts to address the challenge of corruption in peacebuilding contexts, and how effective have these efforts been?

While the focus of this book is predominantly on political corruption, engaged in by persons exercising some form of public authority, we do not want to suggest that corruption in the private sector or amongst international actors does not exist, or that it is mostly benign and of little consequence. As reports into corruption amongst contractors and international military personnel in Afghanistan and Iraq have suggested, these forms of corruption have serious implications for international peacebuilding and stabilisation efforts (Madhani 2010; Bowen 2009). However, given that successful and sustainable peacebuilding undoubtedly requires trusted local institutions - be they formal or informal - corruption within this context seems an appropriate focus for this inquiry.

To frame the contributions to this volume, and to identify some of the core themes that feature across the chapters, the remainder of this introduction examines four issues. First, it will briefly explore some of the problems arising from efforts to define corruption and the implications for our analysis. The second section discusses the impact of corruption on peacebuilding outcomes, while the third highlights the impact of peacebuilding practices on corruption. The fourth section discusses why anti-corruption measures taken during post-conflict transitions have often not achieved their objectives. The chapter concludes with a brief overview of the book.

Corruption is a complex and contested issue. The different definitions of corruption employed by the contributors to this book and their differing assessment of the consequences of corruption for peacebuilding testify to this. These differences reflect diverging views on the role of governance and institutions, different conceptions of peace, and in the case studies, the particular social and political structures of the countries under study. Moreover, these differences merely underline that both context and perspective matter when examining complex social phenomena like corruption, and that care needs to be taken in any effort to apply insights from one case to another.

\section{Conceptualising corruption}

Corruption has become a key lens through which peacebuilders observe the political, institutional and social dynamics in post-conflict societies. Yet growing awareness of corruption as a problem in post-conflict peacebuilding has also resulted in the concept becoming a catch-all term. Invocations of corruption have encompassed very distinct social problems including the mismanagement of public assets, weak and dysfunctional government 
institutions, complex relationships between political actors and public economic assets, and surviving war-time networks. Some of the most popular and widely used definitions of corruption can appear tantalisingly simple and clear, masking a more complex and contested reality. Thus, both the World Bank's (1997a) classic definition of corruption as 'the abuse of public power for private gain', or Transparency International's 'the misuse of entrusted power for private gain', ${ }^{2}$ have been popular with donor agencies, not only because they are relatively broad definitions that capture a wide range of corrupt practices, but possibly also because they suggest that corrupt behaviour can be easily identified, classified and addressed through neat institutional solutions. The analysis in this volume, however, suggests that such broad understandings of corruption not only undermine the analytical usefulness of the term, but they also make the development of effective peacebuilding policies more difficult. While the many different social problems often subsumed under the label 'corruption' could challenge a peaceful and prosperous order, each one requires a distinct response and cannot be understood through the same conceptual lens and addressed using the same instruments.

Defining corruption is also complicated by the fact that as a social concept, its content changes across different social and cultural contexts. Practices that are considered corrupt in some countries might be considered as proper and legitimate in others. For example, in some countries, there are societal expectations of an office holder which arise from family or kinship ties; and some actions, even if they are popularly described and regarded as 'corrupt', constitute an essential part of social and political life (Jordan-Smith 2009; Blundo and de Sardan 2006). As James Scott (1969) and other anthropologists have argued, most contemporary understandings of corruption require a clear and wellestablished distinction between private and public spheres with public authority organised and legitimised along the lines of Weberian legalrational authority (for an overview, see Sissener 2001). Where alternative sources of political authority, in particular authority based on traditions of kinship, are competing with state institutions, and the distinctions between public and private are blurred, corruption is more difficult to identify, as public and private duties often overlap. The difficulty of comparing cases and developing policy prescriptions becomes plain when there is not even agreement on the content of the basic concept under discussion.

Despite this recognition of the cultural specificity of the content of corruption, a range of scholars have identified what Mark Philp in his contribution to this volume has called an 'objective core' of corruption that can help to capture the essence of the concept across different social contexts. Philp suggests that common to all understandings of corruption is its subversion of norms and rules governing public office. Similarly, Wayne Sandholtz and William Koetzle (2000: 34-35) identify three core elements of corruption: 
- Corruption relies on the existence of a well-developed distinction between the public and private sphere, which breaks down in cases of corruption.

- Corruption involves administrative or political favours in exchange for inducements, which can be financial, but can also take other forms, not least the form of refraining from violence against the official or politician providing the favour. ${ }^{3}$

- Corruption involves a violation of shared norms of public office.

While such an approach to defining corruption does not get around the problem that different actors can have different perceptions of whether an act is corrupt or not based on varying societal and cultural norms (as exist between intervenors and local populations), this approach does suggest that a qualified systematic and comparative analysis of corruption is possible.

An alternative path to defining corruption focuses not on its structure, but argues that what distinguishes corruption from other forms of malfeasance is that it is a moral concept. Laura Underkuffler (2009: 37), for example, claims that what is missing from most definitions of corruption is that it 'is an explicitly moral notion; corruption describes, in general parlance, a powerful, all-consuming evil'. There are several problems with such an approach. First, it suggests the existence of a set of universal norms that corruption violates. The existence of such a strong normative consensus on the content of corruption, however, is doubtful. Second, and equally important, such a moral approach deprives us of analytical focus and precision. It excludes a priori the possibility that different forms of corruption might be harmful in different ways and to different degrees; or that corruption might even be beneficial, if only in the short term, and at a certain cost, for example by sustaining a relatively stable order that might be unequal and unjust, but which minimises violence (see for example Nye 1967: 420; see also the contributions by Goodhand, Le Billon, Philp and Reno in this volume). It also ignores the possibility that corruption might be a very rational response to the situation within which individuals find themselves, and be a central part of their coping and survival strategies (see Philp in this volume; Goodhand 2004). Third, such a conceptualisation of corruption brings with it major problems for peacebuilding policy. While postconflict environments appear to be especially prone to corruption, and while corruption can compromise peacebuilding efforts, fighting corruption is not the only objective of peacebuilding actors - nor is it necessarily the most important one. Enabling corruption might be a price peacebuilders have to pay to ensure the participation of warring factions in a peace agreement and to end large-scale violence. If corruption were to be seen as an 'all-consuming evil', akin to genocide, rape and other war crimes, it is difficult to see how such trade-offs could ever 
be morally justified. Peacebuilding involves difficult political and moral choices, and by turning corruption into an absolute moral question, it effectively becomes impossible to prioritise amongst different peacebuilding objectives.

\section{Differentiating forms of corruption}

In light of the complexity of the concept of corruption, one way to improve the understanding of its consequences for peacebuilding efforts is to distinguish between different forms of corruption. Three possible ways of refining the concept stand out: first, by contrasting grand and petty corruption; second, by differentiating corruption across sectors; and third, by examining different practices classed as being corrupt.

One of the most common distinctions that is made in the literature and by policymakers is between 'grand' and 'petty' corruption, at times also referred to as political and administrative corruption (Andvig et al. 2001: 10-12), or as state capture and administrative corruption (World Bank 2000b). Despite the misleading terminology, the grand-petty distinction is not concerned with the scale of corrupt activity, but rather the level at which it takes place - either in the political leadership, or the bureaucracy that implements and administers policy. While the former has undoubtedly had a greater impact on the practices and functioning of the political system because it sustains networks of patronage and distorts the laws and procedures of government (rather than just their implementation), it is petty corruption that is experienced more directly by the population in its daily interactions with the state, for example through favours granted and bribes paid regularly to officials (Delesgues and Torabi 2010). While the impact of these individual acts of corruption on the overall peacebuilding process may be minimal, it undermines citizens' trust in the state. Additionally, petty corruption can become a vehicle for targeting ethnic and political groups; in this way, the routine nature of petty corruption can destroy the perception of state neutrality.

The second way to refine the analysis of corruption is to distinguish between corruption in different sectors (justice, security, procurement) as they differ in importance between different post-conflict countries. In jurisdictions with substantial natural resources such as oil or diamonds, corruption in the regulation of these sectors and the trade in these commodities is likely to be a central challenge to peacebuilding efforts (see Gillies and Dykstra in this volume; Le Billon and Levin 2009; Ross 2004). In countries without substantial natural resources, such as Kosovo, government procurement and control of publicly-owned enterprises are key sites of corruption (Kosovar Stability Initiative 2010).

In many post-conflict countries, it is the police and the justice system which are weak and often perceived to be among the most corrupt institutions. ${ }^{4}$ Corruption in these sectors is particularly problematic as it creates 
the (often justified) perception that some groups or individuals can act with impunity. This limits trust in the state and creates a sense of insecurity, thereby undermining peacebuilding efforts. In the aftermath of the 1999 war in Kosovo, for example, Albanian judges and prosecutors displayed a strong bias in favour of Albanians and against ethnic minorities, especially Serbs. While minorities could barely get a fair trial (sometimes facing detention without charges), former Kosovo Liberation Army (KLA) members literally got away with murder - a situation tacitly condoned by parts of the Kosovar political leadership (Lawyers Committee for Human Rights 1999; O’Neill 2002). Importantly, the reason for this behaviour was not financial gain but threats of violence against judges and prosecutors by former fighters from the KLA, and a more general perception among elements of the Kosovar-Albanian elite that the judiciary was simply an instrument to promote the goal of independence.

Finally, one can distinguish between different practices classified as corruption. The UNODCCP distinguishes between eight different forms of corruption: fraud, illegal political bargains, embezzlement, bribery, favouritism, extortion, the abuse of discretion and conflicts of interest (UNODCCP 2002). Andvig et al. (2001: 8-10) limit themselves to five main forms of corruption - bribery, embezzlement, fraud, extortion and favouritism; while Giorgio Blundo and Olivier de Sardan identify seven basic forms of corruption from a detailed comparative study of corruption in West Africa (Blundo and Sardan 2006). These include commissions for illicit services, unwarranted payment for public services, gratuities, stringpulling, levies and tolls, sidelining and misappropriation. Broadly, these different lists agree on the kinds of practices that constitute corruption, but importantly many of them, such as favouritism, the abuse of discretion, or string-pulling can only be meaningfully examined and judged in their specific social context. Therefore, focusing on different forms of corruption does not avoid the pitfalls of specific societal understandings of the concept. It can help, however, with analysing the specific pathways of corruption in different post-conflict environments, and their impact on peacebuilding efforts.

\section{The impact of corruption on peacebuilding outcomes}

There is a common assumption that corruption has a negative impact on peacebuilding and statebuilding outcomes (i.e. Doig and Tisne 2009). Indeed, the harmful impact of corruption on peacebuilding and reconstruction has been a dominant discourse amongst policy makers and in the media (see for example (CNN 2008; Cockburn 2009; Rubin 2009; PBS Newshour 2010), in particular with regard to Afghanistan and Iraq. Much of the general scholarly literature on corruption further underscores its harmful effects (see for example Mauro 1997a; Rose-Ackerman 1999; Heineman and Heimann 2006; Uslaner 2008). 
There is no doubt about the substantial social and economic costs of corruption, such as lower economic growth (Mauro 1995; Kaufmann and Kray 2002), increased cost of capital for firms (Kaufmann and Kray 2002), and growing inequality (Glaeser et al. 2003). In addition, corruption has been associated with the undermining of trust in society (Seligson 2002; Uslaner 2002), the increase in political instability (Mo 2001), how citizens feel about the performance of their democracy (Anderson and Tverdova 2003), and the entrenchment of patronage networks and wartime elites (Cheng 2011).

Despite the fact that corruption poses a strong threat to economic development, political stability, good governance and state legitimacy, in post-conflict countries the costs of corruption need to be seen in the wider context of peacebuilding, and the additional competing priorities that arise from such environments. As many of the contributions to this volume highlight, inquiries into the impact of corruption on transitions from war to peace require a more nuanced discussion that acknowledges the difficult trade-offs that need to be made in a peacebuilding context. In evaluating the impact of corruption, this discussion will take these priorities into account to argue for a more nuanced understanding of the impact of corruption on peacebuilding outcomes. Corruption can have limited positive effects on peacebuilding through facilitating the "purchase of peace' and in its redistributive effects. However, these positive short-term effects are accompanied by a high long-term price because ultimately, the legitimacy of a post-war state and the health of its political institutions are likely to be undermined by corruption.

\section{Ending violence and cementing peace}

To bring an end to the fighting, peace agreements and power-sharing arrangements that implicitly allow for corruption may be a necessary, if unpalatable feature of peacebuilding. Recent research has suggested that creating institutions that incorporate power-sharing between rival factions helps to resolve the security dilemma that arises at the end of war when factions are still mistrustful of each other (Hartzell and Hoddie 2007), and that power-sharing can help to build trust between warring parties and contribute to a more enduring peace. ${ }^{5}$ In some post-conflict settlements, it has been the opportunities for corruption and patronage that were negotiated as part of the power-sharing agreements that have literally helped to 'buy out' potential spoilers in a conflict. Faced not only with the calamity of war, but also enormous pressures to put an end to it, the goal of international actors is usually to negotiate a settlement that ends the violence as quickly as possible. However, in these situations, there was also a tacit understanding that officeholders would be permitted to exploit the economic opportunities provided by government positions. The economic benefits arising to participants in power-sharing agreements have included assuming control of state resources, building patronage networks and political power 
structures (see Belloni, this volume), allowing illicit economic activities to continue (Cheng 2011), and being able to extract bribes in the awarding of public contracts or concessions (Galtung and Tisne 2007) ${ }^{6}$ However, reaching a deal could mean accepting that the opportunities offered by a settlement could be exploited by corrupt actors. The situation in Liberia, as discussed by William Reno in this volume, is an important case in point.

The conclusion of the Liberian civil war resulted in the divvying up of cabinet positions between the three warring factions which effectively gave them a two-year period to reap the full economic benefits of holding official positions. Western diplomats made this trade-off consciously because they felt that it was the only way to bring an end to the civil war. ${ }^{7}$ Corruption was a price that Western negotiators were willing to pay given the number of people who were being killed at the time. The fact that Liberians were piling up corpses in front of the American Embassy in Monrovia sent a clear message to Western negotiators: do whatever you need to do to end this war immediately. Thus, the first goal of the international community was to stop the fighting.

When it comes to the implementation of peace agreements, international actors tend to prioritise stability over ambitious governance reforms, even if there is a substantial long-term cost of doing so for the post-conflict country (Barnett and Zürcher 2009). The problem, as William Reno points out (p. 000), is that international actors do not have any appetite for genuine political reform if it includes the risk of further destabilising the country; instead, the international community 'may tolerate the incorporation of elements of patrimonial politics with only partial reform'.

Even after a settlement is reached and a country has entered the 'postconflict' stage, accepting corruption can still have useful stabilising effects. In 2005, for example, when the governor of Helmand province in Afghanistan, Sher Muhammad Akhunzada, was found with nine tons of opium and heroin in his basement, the British government (whose forces were deployed in Helmand) pressured President Hamid Karzai to dismiss the governor from his post. However, with his departure the security situation in the province deteriorated dramatically, especially after he directed 3,000 of his followers to join the Taliban when he could no longer pay their wages (McElroy 2009). While Akhunzada's dismissal was not the only factor that contributed to increased violence in Helmand, both Karzai and observers in the United Kingdom have argued that his departure played a critical role in the deterioration of security in the province (Nelson 2008; Lloyd 2008). The Akhunzada quandary suggests that Britain paid a high price for its anti-corruption and anti-narcotics stance.

This example illustrates why donors place such a premium on stability. It also illustrates how stabilisation as a priority has made donors' intentions to crack down on corruption much less credible: those engaged in corruption know that international actors would much rather co-opt potential peace spoilers than confront them and risk a return to violence. 
Thus, one unintended consequence of 'buying' the peace is that international actors have typically condoned the institutionalisation of corruption because of overriding concerns about stability (see also Keen 2000). The other problem with 'buying' the peace is that it is difficult to know what exactly is being bought. Returning to the Afghanistan example, the consequences of ceding control of wide swaths of the country to be ruled by corrupt local leaders in the aftermath of the 2001 invasion may have ultimately been the undoing of Western military operations in the country.

There are other potentially dangerous consequences of such an approach. The prospect of sharing in a 'peace dividend' can spark the proliferation of armed groups who seek to be included in the peace agreement, as happened for example in Burundi (Uvin and Bayer 2011). Similarly, factions (both the leadership and ordinary 'foot-soldiers') feeling that they are not getting their fair share of the peace dividend might resort to violence to enhance their bargaining position, thereby destabilising the political situation and even leading the country back to war.

\section{Redistributive effects}

Corruption can also have a stabilising effect in another way: through its local redistributive effects. In countries where patronage politics structure political relationships and interactions, these structures can also be stabilising if managed well (see, for example, Reno 1995), no matter how objectionable they may seem to international peacebuilders. When the proceeds of corruption flow through these networks during a period of political instability, then these funds can be used to cement loyalties and relationships which can, in turn, help to stabilise the emerging post-war order. The key to this reasoning hinges on how widely and deeply the benefits are redistributed and whether this redistribution can be linked to the broader social order. The latter depends on the particular local norms of public office and citizens' expectations of office holders (Jordan-Smith 2009). For example, if a significant sum from an important bribe is redistributed widely through political patronage networks, then the redistribution of these funds should serve to strengthen an existing political order. Certainly, if the proceeds of a bribe are not redistributed, the effects can be violent. An example from Liberia illustrates this tension. The management of the Sinoe Rubber Plantation, one of Liberia's largest, had historically been a contentious issue for local residents. When the war ended, RUBREMICCI, the company that officially held the management contract was eager to evacuate those who were illegally occupying the plantation. The company allegedly offered three key individuals a bribe to buy their cooperation. One of these three individuals (Paulson Garteh) reportedly returned and shared his bribe with the community, turning himself into a local hero in the process. The other two people, who chose not to share their bribes, were rumoured to have received death threats from 
community members (UNMIL 2005a). This example illustrates that while corruption in itself is an important consideration, the question of whether a bribe is retained solely by the individual who receives it or whether it is redistributed locally can affect peacebuilding outcomes.

The Liberian example reveals that relying on corruption to lead to stabilising redistributive effects is a risky proposition. In his chapter, Philippe Le Billon points out that as 'groups empowered by the outcome of the war continue to sustain dominant political and economic positions through corruption, they may prevent the redistribution of power by stifling institutional checks and balances' (p. 000). As a result, inequalities become entrenched and could give rise to new grievances and sources of conflict between and within groups. You and Khagram (2005) argue that these types of entrenched inequalities create vicious cycles which are difficult to break out of because inequality creates a greater social tolerance for corruption, which in turn further reinforces inequality. While this particular dynamic may not result in an immediate return to war, the quality of peacebuilding outcomes will certainly suffer.

\section{Corrosive effects}

While corruption can have stabilising effects in the short term, researchers generally agree that its long-term impact is overwhelmingly negative. Thus, in most peacebuilding contexts there is an implicit trade-off whereby corruption is tolerated in the short-term in order to end violence and aid stability, but the foundations for long-term development of state institutions are undermined as the capacity and legitimacy of the state suffer damage. These effects are corrosive in nature; they affect people's perceptions of the state, creating expectations of corruption and bribery not only at the highest levels of government, but throughout a state's institutions. Once people's expectations are gradually recalibrated to anticipate corrupt interactions, these norms of corruption will perpetuate themselves. If one takes the long view, it is possible to see how the institutionalisation of these interactions can lead to deeply-entrenched patterns of state corruption as described in several studies of African politics (Bayart 1989; Bayart et al. 1999; Chabal and Daloz 1999; Jordan-Smith 2009). As the state comes to be seen as increasingly predatory, corruption becomes a rational response to the context. Uslaner suggests that where there is a culture of corruption, 'people make payments because there is no way out' (2008: $6)$. These attitudes are further reinforced when civil servants take their cues on the integrity of holding public office from politicians and senior officials who regularly accept bribes. As people come to perceive their officials as generally corrupt, it becomes correspondingly difficult in the aftermath of conflict to re-establish trust in government. Citizens lose faith in the justness of their institutions and turn to non-state mechanisms to meet their needs. Escaping this cycle becomes all the more difficult 
because citizens are more likely to disengage from the political process once they believe these institutions have been compromised (Seligson 2002; Anderson and Tverdova 2003).

In environments rife with corruption, the problems accompanying political self-selection become further amplified: corruption becomes central to the maintenance of patronage networks on which political power is based, making it difficult for those without such networks to compete for power, and potentially dangerous for those who want to fight corruption to do so. In the extreme, there is a danger that those who are benefiting from corruption will exploit their position by using state resources to violently defend their patronage networks. Even in a democratic system, any outsider entering electoral competition would need sufficient financial resources to campaign against those who are part of the corrupt system; this dynamic then makes getting elected an even more expensive proposition which further fuels corruption. Thus, when a government's reputation for corruption starts to affect the selection of political leaders, the quality of political leadership will decline.

\section{The impact of peacebuilding on corruption}

The international community can play a critical role in the post-conflict transition process of most states, especially by sustaining peace operations and through its funding of humanitarian and development assistance. While the involvement of international actors shapes the post-war environment, it also structures opportunities for corruption. Thus, to understand the character of corruption in post-conflict countries and its impact on peacebuilding operations, and to be able to develop strategies to contain it, it is critical to fully understand how contemporary peacebuilding policies and practices can fuel it. Ultimately, these policies and practices are under the control of international peacebuilding actors and can be changed if they encourage corruption; in contrast, peacebuilders have little influence over corrupt practices of local elites, in particular if they are rooted in local culture or tradition.

This section examines five key dimensions of contemporary peacebuilding that have further fuelled or entrenched corruption. These factors are deeply entrenched in how the international community provides assistance to post-conflict countries and are extremely difficult, if not impossible, to change. They include the rapid disbursal of aid in the immediate aftermath of conflict, the reliance on local partners in the implementation of peacebuilding efforts, the primacy of stability, the dominance of counter-terrorism policies and peacebuilders' emphasis on democratisation, in particular the holding of elections soon after the end of a war. This section ends with a discussion of several peacebuilding practices and policies that should mitigate corruption and could realistically be implemented by any individual donor state. 


\section{The early and rapid disbursement of aid}

As von Billerbeck highlights in her chapter in this volume, the rapid inflow of large amounts of aid, with the economic distortions that it involves, and the rent-seeking opportunities it offers, 'makes post-conflict settings rife with opportunities for corruption' (p. 000). While external assistance is needed, these funds usually cannot be fully absorbed immediately after the signing of a peace agreement (Collier and Hoeffler 2004b). Given that there is more aid money than capacity to absorb it, the 'excess' money is more likely to be misspent, creating greater scope for corruption.

Often, the amounts of money that are brought in as a result of peacekeeping missions and humanitarian aid are so large relative to the local economy that peacebuilding itself becomes a local industry (Ignatieff 2002). For example, in 2004-2005, the budget for Liberia's peacekeeping mission was set at US\$865 million - this amount dwarfed the country's official GDP which was approximately US $\$ 511$ million. ${ }^{8}$ This figure does not even include any form of bilateral or regional aid, nor does it include funds spent by any of the UN agencies. After years of conflict, it is easy to see how the arrival of the international community can turn a fragile local economy upside down (Carnahan et al. 2006) and how opportunities for corruption are created.

It is also worth noting that for the local population, the dollar amount of international assistance will be even larger after taking purchasing power parity into account. While an expatriate NGO worker or UN programme officer, for example might not consider US\$5,000 or US\$10,000 to be huge amounts of money, in many post-conflict countries, this amount could be enough to buy a plot of land and build a respectable family house. Amounts that seem insignificant as part of multi-million dollar aid projects actually loom large over local livelihoods: having an opportunity to secure one's future, pay for medical treatment for loved ones, or guarantee access to higher education for one's children makes corruption much more tempting. Indeed, the amounts of money that the international community brings with it to a post-conflict environment are so large that some observers have argued that in the case of Afghanistan, there is now a strong incentive to maintain an environment of insecurity because so much of the local economy is dependent on the flow of international assistance (Wilder and Gordon 2009).

Analysts have argued that the problem of corruption associated with development aid could be addressed by gradually phasing aid in and building it up over several years as the capacity of a post-conflict government increases (i.e. Collier and Hoeffler 2004b). However, the reality is that there is only a limited window of time for raising large amounts of aid after a conflict comes to a formal end, as other crises soon capture the attention of donors. Moreover, in the case of humanitarian aid, quick 
delivery is prioritised, as people's lives are at stake. ${ }^{9}$ However, time pressure also creates opportunities for corruption. In some cases, if 'speed money' is not paid, then food and medical supplies are not delivered, container cargo remains stuck in customs warehouses, and NGO operating licenses get stuck in red tape. When the situation is critical, international actors might feel compelled to make that payment, thereby fuelling an expectation that corruption is acceptable, feeding existing cultures of corruption and strengthening those actors who have the power to control access to those in need of humanitarian assistance (Shearer 2000). This sort of inconsistent behaviour signals to the political elite and the local population that donors are not serious about fighting corruption.

\section{Reliance on local elites}

While the relationship between external and local actors is often characterised by unequal power, dependency and the denial of local autonomy (Chandler 2010), it is important to note that international peacebuilding actors are also highly dependent on the cooperation of local actors, especially elites. Establishing control over territory requires substantial military forces that intervenors are normally unwilling to provide and sustain, therefore local political elites need to be co-opted to sustain stability and to implement various peacebuilding objectives. However, for international peacebuilders, part of the price of co-opting local elites could mean a greater tolerance of local corruption. Successful peacebuilding and statebuilding relies also on local knowledge and support for establishing policies and institutions - something that external intervenors will inevitably lack. As local elites are likely to have interests that diverge from those of external peacebuilding actors (not least a keen interest in maintaining their power), this reliance leads to classic principal-agent problems, and in particular to the problem of information asymmetries, as local partners become gatekeepers, controlling the flow of aid money into the community (Jackson 2005; Nakaya 2008).

This type of information asymmetry creates opportunities for corruption: assistance can be re-directed from those in need to those who are loyal, and projects can be sub-contracted to cronies. The information asymmetries and the difficulties of monitoring these practices and understanding the complex social relations that fuel them reduce the risk of corrupt actors getting caught, and make it extremely challenging to eliminate corruption from a post-conflict environment.

\section{The primacy of stability}

In a post-conflict situation, international actors are worried most about a country returning to war. Peacebuilders worry that renewed violence would threaten the legitimacy of peacebuilding efforts and the credibility of the organisations involved. As the political situation grows calmer and 
the chance of war diminishes with each passing day, the stakes for keeping a country violence-free grow ever higher. This has often made peacebuilding actors unwilling to tackle corruption amongst actors with a capacity for violence because they might directly threaten the peacebuilding process if the corrupt structures and practices sustaining their power or their wealth are challenged.

This dynamic is evident in Kosovo where the EU Rule of Law Mission (EULEX) and the EU's International Civilian Office (ICO) have allowed parallel authority structures to persist in the Serb-populated north of the country even though these structures are widely acknowledged to be rife with corruption and associated with organised crime elements. Similarly, EULEX and the ICO have been mostly unwilling to confront notoriously corrupt members of the Kosovo Albanian political elite for fear that their arrest and prosecution could lead them to mobilise violent protest.

\section{Counter-terrorism}

In Afghanistan and Iraq, the prioritisation of counterterrorism and counterinsurgency over peacebuilding and statebuilding has come at the expense of safeguarding the power of all those who are willing to fight al Qaeda, the Taliban, and any other 'terrorist' group, and a tacit acceptance of their often corrupt behaviour. A financial crisis at the largest bank in Afghanistan illustrates how the counterterrorism imperative competes with corruption concerns. In January 2011, experts warned about the potential collapse of Afghanistan's banking system, as Kabul Bank tried to cope with potential losses of US $\$ 900$ million resulting from fraud, mismanagement and corruption. Contributing to these losses were loans and grants made to government ministers, as well as millions of dollars spent by the bank on helping to re-elect President Karzai (Rubin 2009). Importantly, US State Department cables released by WikiLeaks reveal that both Afghan and Western regulators knew broadly about the massive fraud and corruption problems but chose to concentrate their attention on terrorist financing. Addressing corruption was not a priority, even though it undermined the legitimacy and stability of the central government. The emphasis on counterterrorism has also permitted key public figures central to counterterrorism efforts in Afghanistan to enrich themselves by exploiting their public positions.

\section{Democratisation and early elections}

The establishment of democratic institutions has been a central pillar of international peacebuilding efforts. Specific elements of post-war democratisation, in particular the holding of elections early in the post-war period, have been criticised for fuelling violence and entrenching and democratically legitimising war-time elites (Carothers 2007; Paris 2004; and Snyder 2000). Democratisation, and in particular early elections, however, can also 
fuel and entrench corruption. Studies show that clientelistic politics, the increased ability of rent-seekers to access public officials, and weak institutional checks and balances associated with democratisation processes all increase opportunities for corruption and reduce the risk of getting caught (Rock 2007). In addition, rapid democratisation in post-conflict countries can lead to what Paul Collier has termed the 'selection effect' ${ }^{10}$ whereby the most corrupt individuals end up controlling government. The reasoning is simple: electoral campaigns require money, and those most able to fund such campaigns in the aftermath of civil war are also the people who are most likely to be powerful and corrupt. ${ }^{11}$ The result is government leadership that tends toward corruption, and an electoral process that is likely to entrench and democratically legitimise war-time elites.

In light of this dynamic, it might be tempting to call for the postponement of elections to create opportunities for the emergence of a more diverse range of political candidates (including non-corrupt ones). However, this argument ignores the fact that it is often very difficult for external actors to postpone elections. There is usually strong popular demand for elections (as highlighted by the high voter turnouts that often characterise the first post-conflict election in a country). Also, promoting democratic governance is central to the legitimacy of peacebuilding interventions; denying or significantly delaying elections would undermine the legitimacy of external peacebuilding actors and their practices. Who, in the absence of elections, would have the legitimacy to govern (Reilly 2004; Zaum 2007)? Thus, the politics of sovereignty and legitimacy often make it unfeasible to significantly delay elections.

Nevertheless, international peacebuilders could do more to level the electoral playing field, facilitate the emergence of non-corrupt actors, and discourage corrupt behaviour during the election campaign. This could include laws to control the financing of political parties and election campaigns, as suggested by the head of Iraq's Commission on Integrity (Karim 2011); the provision of free media coverage (e.g. via UN radio and TV stations) to all serious candidates; supporting the development of political parties with programmatic agendas (as opposed to parties based on ethnicity or individuals); and pushing for independent national electoral commissions with robust powers.

\section{Mitigating corruption}

Some of the ways in which international peacebuilding is currently organised makes it difficult to entirely eliminate corruption. However, some international peacebuilding practices could be altered or better managed to reduce corruption. This section briefly examines several practices that, with some effort, can realistically be changed to mitigate corruption.

The first issue is the poor monitoring of donor-funded projects by donors. Donors do a poor job of monitoring their money and evaluating 
whether the intended objectives have been achieved. In part, this is because development projects are often sub-contracted out to local NGOs by donor agencies; making accurate monitoring of progress and assessing outcomes more difficult. The information asymmetries arising from this makes corruption more tempting because the agent has a lower risk of getting caught. The problem is compounded when donors hire international NGOs who in turn hire local NGOs, creating a nested principal-agent problem.

In Afghanistan and Iraq, the general problem of poor monitoring has been exacerbated by the decision to conduct many transactions on a cash basis. This has resulted in unbureaucratic practices which vastly increased the opportunities for corruption, fraud and waste. For example, Stuart W. Bowen Jr., the United State's Special Inspector-General for Iraq Reconstruction, has written about how the US government's Coalition Provisional Authority (CPA) was conducting official business using duffel bags full of cash in January 2004 (DeYoung and Pincus 2009). Bowen referred to the mismanagement of US $\$ 50$ billion of reconstruction money as resembling the work of a giant 'ad hoc-racy' (ibid.).

However, the problem can be mitigated to some extent through effective monitoring and evaluation. Despite the fact that outsourcing to local partners increases the likelihood of funds being misspent, donors often deliberately choose not to expend resources and effort on monitoring their projects. For example, a field experiment conducted by Ben Olken (2007) demonstrated that for a World Bank road-building project, informing project managers that the central government would audit all of the projects (instead of just 4 per cent of projects) and then making the results of the audit public at a village meeting actually reduced corruption by 8 per cent in highly-corrupt Indonesia. This result suggests that top-down audits combined with the threat of social sanctions can have a powerful effect, yet most donors have chosen not to invest their resources in this way.

The second issue concerns donor states' own departmental budget practices. Typically, budgets are set annually and funds that have been allocated to a particular line item must be spent by the end of the fiscal year. If there is any unspent money, then that particular line item is likely to be reduced by the unspent amount in the budget for the following year. For a programme officer in a donor state, the goal is to give the money away and get it out the door; she is evaluated on whether that money is spent, not on the impact that the money has had. Ultimately, the officer does not want her budget to be cut so there is pressure to turn a blind eye if and when corruption, fraud and waste become problematic. Given competing demands on her time, she has little incentive to follow up and be seen within her organisation as a 'troublemaker'. If donors were to change how internal budgets are set each year and how programme officers are evaluated, this should help mitigate corruption.

Finally, the international community does not have a strong record when it comes to punishing governments, or even local partners, for acts of 
corruption (but see Dwan and Bailey 2006). Organisations are rarely held to account and there are few repercussions for the individuals responsible for project implementation or project monitoring. There are a variety of factors which contribute to this poor record. From a practical perspective, there is usually no point in trying to prosecute the individual given that the judicial system in a post-conflict state is unlikely to be functioning properly. Because donors, IOs and NGOs are concerned about the implications for their reputations (both domestic and international) that would accompany any hint of corruption on their projects, they are also unlikely to press charges or make public the inadequacy of their monitoring systems. Finally, irrespective of corruption, international actors will need to continue working with these organisations and individuals because the alternatives are limited; they cannot afford to lose access to critical local partners so it becomes easier to stay silent. For these reasons, those who work directly for international peacebuilding actors and are caught accepting or demanding bribes are usually dismissed from their position with no further consequences; for local partners found to be corrupt, all that donors can realistically do is to exclude them from a specific project.

The fact that international peacebuilders are unwilling or unable to institute any kind of meaningful deterrent makes engaging in corruption a lowrisk, high-reward activity. Research by Alesina and Weder (2002), for example, finds that at the macro-level, there is no evidence that despite some variation between donors, less corrupt countries receive more bilateral or multilateral aid. While donor rhetoric has heavily promoted transparency, good governance and anti-corruption efforts, donor behaviour has shown that corruption levels do not, on the whole, affect levels of development assistance. $^{12}$

Peacebuilders have often structured the environment in ways that have facilitated corruption. While some amount of corruption is inevitable in a post-conflict setting, peacebuilding actors can still control how and when they disburse aid; they can choose who to partner with and institute appropriate deterrents; and they can change their policy priorities. As discussed, the premium placed on stability, the emphasis on early elections, and the dominance of the counterterrorism agenda each contribute to a permissive environment where corruption is more likely to thrive. These factors are under the control of international actors. Yet until donors credibly signal that corruption really matters, the rhetoric on corruption will not be taken seriously by local partners.

\section{Obstacles to anti-corruption efforts and peacebuilding operations}

As the case studies and chapters show, anti-corruption efforts in postconflict countries have focused on strengthening state capacity; on increasing transparency in decision-making, especially in spending decisions; and 
on the accountability of public actors, through both formal and informal monitoring processes. However, despite the substantial resources dedicated to these efforts, the impact on corruption has been limited, with most post-conflict countries lingering at the bottom of global corruption and governance indices. Looking at some of the characteristics of international anti-corruption efforts in peacebuilding operations can shed some light on why corruption has remained such a problem. Four issues stand out: internationalising governance functions; an emphasis on formal institutions; a focus on host-state institutions; and a reliance on executive fiat.

\section{The internationalisation of governance functions}

A substantial number of peacebuilding operations have witnessed the internationalisation of governance functions, either comprehensively, as with international transitional administrations in Kosovo or East Timor (Caplan 2005; Zaum 2007) or the CPA in Iraq (Fox 2008), or more selectively, with internationals controlling the police, budgetary powers, or the justice system. Examples of the latter include the Governance and Economic Management Assistance Program (GEMAP) in Liberia that introduced international experts with co-signature authority into key ministries and public enterprises to enhance transparency and accountability, especially with regard to revenue collection, procurement and spending decisions (see Reno's chapter in this volume); or the EU's Rule of Law Mission EULEX in Kosovo, whose international police force, judges and prosecutors have the authority to investigate and prosecute corruption cases (Zaum 2009).

While aiming to enhance transparency and accountability, such internationalised set-ups also aim to strengthen the capacity of these institutions and train local officials. In some respects, such mechanisms have been quite successful: GEMAP contributed to a tripling in Liberian tax revenues, while EULEX has begun to investigate a senior government minister and popular former commander of the KLA for corruption associated with road building. However, all such mechanisms face obvious problems of sustainability, for if they fail to address the underlying organisation of corruption and the social and economic structures that fuel it, corrupt actors can simply choose to wait out the international presence. Because of the fact that these types of intrusive anti-corruption mechanisms compromise norms of sovereignty and self-governance, they can be politically costly to maintain and fuel local resistance to the wider international peacebuilding effort. ${ }^{13}$

\section{Focus on formal institutions}

In their anti-corruption efforts, peacebuilding operations have focused on building and strengthening formal anti-corruption institutions, such as 
anti-corruption commissions (ACCs) (see Heilbrunn's chapter in this volume), the judiciary, and procurement systems based on international best practices. However, these efforts often fall short as anti-corruption institutions are insufficiently resourced and insulated from political influence. As John Heilbrunn highlights in his chapter, ACCs can only be effective if they have strong political support, have adequate financial resources, and are given a strong official mandate. However, it is rarely in the interests of local elites to establish independent and well-resourced institutions that threaten the networks that sustain their power. In Kosovo, for example, the anti-corruption agency has lacked substantial political support, and has been starved of funds: with a budget of merely half a million euro and a small staff it has no capacity to investigate corruption allegations (Kosovar Stability Initiative 2010: 19).

In addition, the focus on strengthening anti-corruption institutions is rooted in the idea that weak formal institutions fuel corruption. However, as the case studies show, corruption in post-conflict countries is also the consequence of concomitant informal power structures that fuel and shape relationships of corruption. Such efforts to strengthen formal institutions are rarely accompanied by similar efforts to weaken or co-opt these informal structures, limiting the impact of anti-corruption reforms, as highlighted in the chapters on Liberia and Sri Lanka.

\section{Focus on host-state institutions}

Peacebuilding operations tend to focus their anti-corruption efforts predominantly on the actions and institutions of the host state, rather than on the practices of public or private international actors such as businesses, NGOs, or international organisations. However, in post-conflict countries one cannot really understand - let alone successfully fight - corruption without attending to the role of international actors and structures. As discussed earlier, the scale of aid and the way in which it is disbursed, has important consequences for corruption (see also von Billerbeck's chapter). Similarly, the exploitation of natural resources and the networks of corruption that accompany it are inextricably linked to international markets. Yet, with a few notable exceptions, international anticorruption efforts have focused predominantly on the role of the post-conflict state - despite the fact that external actors and structures play an important role.

While there has been a strong campaign for greater transparency in aid programmes, some donors have been less than forthcoming in detailing how their aid money is spent. A recent assessment by the Publish What You Fund (PWYF) campaign notes a glaring lack of primary data that would allow for comparisons between countries and programmes on how and where donors have allocated funds (PWYF 2010). While civil society 
encourage transparency and accountability in the natural resource sector, Alexandra Gilles and Page Dykstra argue in their chapter that with the growing international competition for natural resources, the desire of Western governments to put pressure on their mining companies has declined. Instead, the emphasis has shifted to encouraging recipient developing country governments to be more transparent about their natural resource income under the Extractive Industries Transparency Initiative (EITI). On the other hand, as a consequence of an effective campaign by anti-corruption NGOs in the United States, the 2010 financial reform bill included provisions requiring resource extraction companies to disclose all payments made to governments for oil, gas or minerals. As the bill takes effect, it will become clearer whether these efforts to enhance transparency will have the desired effect on corruption.

\section{Anti-corruption by executive fiat}

In peacebuilding contexts where external actors exercise executive authority, some of their envisaged anti-corruption measures were notable for their sweeping nature, and characterised by little regard for proper procedural safeguards, and in some instances, for flaunting rule of law principles. As such measures are often intended to demonstrate the decisiveness of either the government or of international actors, they run the risk of being based on simplified perceptions of the sources of corruption rather than a clear understanding of how corruption is actually working, and to compromise the very principles of good governance that peacebuilding actors purport to support. The lack of procedural safeguards and the scope of the actions can have important consequences for a country's institutions. Two examples highlight the problems with these measures.

The first relates to the judicial reform efforts in Bosnia and Herzegovina $(\mathrm{BiH})$, as described by Per Bergling in his chapter. When the original programme to weed out corrupt judges (based on complaints from the public and formal investigations into these complaints) yielded only seven dismissals of judges and prosecutors, the Office of the High Representative replaced it with a new programme in 2002, requiring all judges and prosecutors to re-apply for their jobs. This reversed the burden of proof on the individual applicants, even if they had been promised life tenure following a review of the judiciary two years earlier. As a report from the Independent Judicial Commission (staffed with international experts) noted with disarming honesty, the problem was that the original programme required 'a certain amount of proof be produced to support a finding that a judge/prosecutor is not fit to hold office' (Knaus and Martin 2003: 65). This kind of anti-corruption project did little to advance the rule of law, or to promote the general liberal democratic principles which the OHR and the wider international community have used to justify their presence and intervention in BiH. Not surprisingly, the 
programme was widely criticised both locally and internationally, though some analysts note that it contributed to a decline in corruption in the justice system (see Per Bergling's chapter in this volume).

The second example concerns a proposal to reform the procurement system in Kosovo in 2010. Procurement had previously been identified by donors and local analysts alike as one of the key focal points of corruption in Kosovo (EC 2010). In 2010, leading government members proposed to address the problem by firing and replacing all procurement officers. For a while, this proposal had substantial support from major donor countries ${ }^{14}$ but was ultimately abandoned. A closer analysis of the procurement system (2010) by the Kosovar Stability Initiative highlights that such a policy - had it been implemented - would actually have made corruption worse in the procurement system. The mass firing and replacement of the officers would have failed to address two important underlying factors contributing to the corrupt character of the system: the poor quality and limited training of procurement officers, and their vulnerability to pressure from local and national politicians. As civil servants, procurement officers should have been protected from the threat of political dismissal. However, local and central government agencies chose to ignore the existing legal framework, leaving procurement officers vulnerable to pressure, including threats of violence and in some cases, actual violence. Firing all of the procurement officers would only have reinforced their vulnerability to political pressure.

\section{Conclusion}

Ultimately, there is no simple way to summarise the relationship between corruption and peacebuilding; it is at once deep, complex and varied. Instead, we offer two concluding ideas.

First, corruption is a political problem that requires a political solution; a technical approach will not succeed on its own. In practice, this means that establishing anti-corruption institutions and passing reforms are unlikely to be effective without real political support from both donors and post-conflict governments - no matter how well-funded they are or how well-designed the anti-corruption programme is. Corruption is difficult to tackle because there are underlying structural imperatives that make it a rational strategy in post-conflict societies. In the post-conflict context, the approach that is most likely to achieve long-term success is to embed anti-corruption reforms within efforts to create legitimate political institutions. Ideally, these two agendas should be seen as complementary; certainly, anti-corruption reforms will be more credible if the implementing institution is also credible.

Finally, corruption is a double-edged sword. It can be used in the shortterm to craft a peace where the spoils of war are divided amongst the fighting factions; in some cases, it may be the only way to provide the stability 
needed to achieve other peacebuilding objectives. But in its tacit acceptance, it also sows the seeds for undermining the capacity and legitimacy of state institutions. The challenge is for international actors to balance the imperatives of putting an immediate end to the violence without undermining the sustainability of the long-term peace.

\section{Organisation of the book}

This book is divided into three Parts. The first Part addresses how corruption is conceptualised in a peacebuilding environment. Mark Philp begins this volume with a theoretical exploration of corruption and how a postconflict environment can shape what is or is not considered corruption in different contexts. Susan Rose-Ackerman then examines in greater depth what corruption in a post-conflict government might look like and what needs to be done by domestic and international leaders to successfully achieve reforms. The next two chapters focus more directly on the impact of the international community; first, by examining how liberal peacebuilding fosters corruption in Philippe Le Billon's chapter, and then by analysing how international aid affects corruption in the domestic context in Sarah von Billerbeck's chapter.

The second Part consists of a series of case studies illustrating many of the peacebuilding dynamics identified in the first Part. The country cases highlight the contested character of corruption, and illustrate how factors such as culture and tradition, historical context, and human agency contribute to the relationship between peacebuilding and corruption. In $\mathrm{BiH}$, Michael Pugh and Boris Divjak discuss the persistence of informal local networks in the aftermath of the war; while Per Bergling examines how perceptions of local corruption gradually created the impetus for the wholesale firing of the Bosnian judiciary. William Reno takes a comparative approach to analysing corruption in Liberia, contrasting its destabilising effects with the stabilising influence of corrupt networks in East Asia. In his chapter on Afghanistan, Jonathan Goodhand shows how corruption is deeply wrapped up with drug trafficking. Using the concept of joint extraction regimes, he argues that drugs and corruption have given the central government a degree of influence in the north that it does not have in the north. In the chapter on Iraq, Robert Looney focuses on how the disintegration of generalised trust played into the country's political corruption. The final case study by Zachariah Mampilly takes a historical perspective to argue that the changes that occurred in Sri Lanka's political economy during the civil war ultimately informed the nature of corruption in the post-conflict period.

The third Part of the book focuses on anti-corruption measures. In his chapter on ACCs, John Heilbrunn suggests that these institutions, rather than offering a quick fix to corruption, can contribute to the consolidation of anti-corruption and transparency norms through processes of 
socialisation. He concludes that a more long-term perspective is needed when assessing the success of anti-corruption efforts. In the next chapter, Roberto Belloni examines the dual role that civil society has played, in some cases leading the fight against corruption by publicly exposing corrupt activities, but in other instances being co-opted by dominant patron-client networks. In the final chapter of the book, Alexandra Gillies and Page Dykstra scrutinise the reasoning and logic that underpin two important transparency initiatives in the management of natural resources: the EITI and PWYP. Their analysis suggests that the success of these programmes can ultimately be attributed to committed leadership, a supportive governance environment and optimal timing in implementation.

Both peacebuilding actors and analysts continue to wrestle with the problem of corruption and how it impacts efforts to end violence and build or rebuild a reasonable and stable political order in war-torn countries. As the contributions to this volume show, it is too simplistic to frame this debate in terms of tensions between clear categories, such as corruption versus development, or anti-corruption versus stability (see also Jarstad and Sisk 2008). In this book, we have included a wide range of opinions on the character of corruption, on its consequences for peacebuilding and on the best ways to address these problems. While not all contributors to this volume necessarily share the assessments in this introductory chapter, they concur that the reality of both corruption and peacebuilding is too complex to be captured in simple, catch-all concepts, and that this relationship is too varied to be addressed with universalist policy prescriptions.

\section{Notes}

1 We would like to thank Emily Paddon, Michael Urban, Elly Harrowell and the participants of the first Oxford Conference on Governance and Transparency for their helpful comments and suggestions on earlier drafts of this chapter.

2 See Transparency International website. Online, available at: www.transparency.org/news_room/faq/corruption_faq, accessed 18 January 2011.

3 Arguably an official acting against the public interest because she was threatened with violence is not corrupt, however, the person threatening her would be considered corrupt, and so would the transaction itself.

4 See for example Delesgues and Torabi (2010: 30) for perceptions of corruption in rule of law institutions in Afghanistan.

5 For critical views on the costs of power sharing, see Tull and Mehler 2005; and Mehler 2009.

6 Examples include the 2002 Global and All-Inclusive Agreement in the Congo, and the trust fund set up to buy the RENAMO rebels' assent to the peace agreement in Mozambique.

7 American official familiar with Liberia's peace negotiations. Personal interview, May 2007, Monrovia.

8 See UNdata website. Online, available at: http://data.un.org/CountryProfile. aspx? crName $=$ Liberia.

9 On the complex moral issues and political issues raised by the delivery of humanitarian aid, see Keen 1994; and Anderson 1999. 
10 ODE Talks Podcast: Interview with Professor Paul Collier, 24 November 2010, AusAID, Office for Development Effectiveness. Transcript online, available at: www.ode.ausaid.gov.au/publications/pdf/transcript-colliernov2010.doc accessed 8 February 2011.

11 For example, in the 2009 Afghanistan election, voting cards were being sold for US $\$ 10$ each (about $£ 6$ ) by Kabul traders. In the north of the country, one tribal leader claimed that 'he had been offered thousands of dollars by campaign teams in exchange for delivering large blocks of votes' (see Pannell 2009).

12 One important exception has been the Millennium Challenge Corporation which explicitly challenged this practice. See Millennium Challenge Corporation website, online, available at: www.mcc.gov/.

13 This was reflected in the cautious response from other African leaders to the GEMAP in Liberia, seeing it as 'a threatening precedent for eroding African Sovereignty' (McGovern 2008: 341).

14 Personal interviews with representatives from major donor countries, Prishtina, July 2010. 


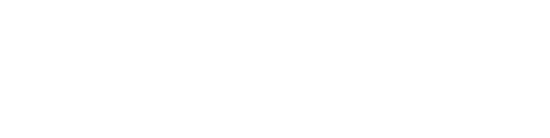

